\title{
Danazol in non-splenectomized patients with refractory idiopathic thrombocytopenic purpura
}

\author{
D.Z. Edelmann ${ }^{1,2}$, B. Knobel ${ }^{2,3}$, I. Virag' ${ }^{1}$ and D. Meytes ${ }^{1,3}$
}

\author{
Departments of ${ }^{1}$ Hematology and ${ }^{2}$ Medicine 'B', The Edith Wolfson Medical Center, Holon 58100 , and \\ ${ }^{3}$ The Sackler Faculty of Medicine, Tel-Aviv University, Israel
}

\begin{abstract}
Summary: Seven non-splenectomized patients with chronic refractory idiopathic thrombocytopenic purpura were treated with danazol $800 \mathrm{mg}$ daily. All were glucocorticoid failures and four were refractory to all additional previous therapy. Five patients benefited from danazol and in two sustained normal platelet counts, for over 44 and 51 months, were observed. We conclude that danazol is useful for long term management of otherwise refractory idiopathic thrombocytopenic purpura. The advantage of danazol over splenectomy as a first line treatment in steroid failure is suggested.
\end{abstract}

\section{Introduction}

Thrombocytopenia in most patients with idiopathic thrombocytopenic purpura (ITP) responds to steroids. ${ }^{1-3}$ Splenectomy is considered the treatment of choice in steroid failures, ${ }^{1,4,5}$ followed by immunosuppressive therapy when needed. ${ }^{1,2}$ Danazol, a derivative of ethinyl testosterone, is a synthetic attenuated androgen with reduced masculinizing capacity, initially formulated for the treatment of endometriosis., ${ }^{2,3,6-8}$ Favourable results of danazol therapy in refractory ITP were first described by Ahn et al. in 1983. ${ }^{6}$ In the few reports published since, the authors were almost equally divided between those who achieved similar results ${ }^{8-10}$ and those who failed to show a significant response. ${ }^{3,11}$ Since splenectomy may have operative and in particular considerable postoperative complications, we considered it worthwhile to examine the effect of danazol in patients with ITP, prior to splenectomy.

\section{Materials and methods}

Seven patients with chronic refractory ITP, who refused splenectomy, were studied. Patients' data and treatment regimen before danazol are presented in Table I. Six were steroid failures and in one steroids were contraindicated. In five patients a daily dose of prednisone $(60-150 \mathrm{mg})$, during at least 6 weeks, failed to raise platelet counts to adequate levels. In one patient (No. 5) although a transient response, up to $142 \times 10^{9} / 1$ platelets, was noted, steroid withdrawal was associated with a

Correspondence: D. Meytes, M.D.

Accepted: 9 May 1990 decline in platelet counts and bleeding. The addition of immunosuppressive therapy in five patients failed to raise platelet counts.

All patients were treated with a fixed dose of danazol (Danocrine ${ }^{\circledR}$, Winthrop) $800 \mathrm{mg}$ daily for at least 3 months. Evaluation of response was scaled as follows: 'excellent' - when platelet count rose to $100 \times 10^{9} / 1$ or more and remained there for at least 2 months with continued therapy; 'good' - a sustained increase to $50-100 \times 10^{9} / 1$; 'transient' when the rise was to more than $50 \times 10^{9} / 1$ and lasted less than 2 months; 'poor' - when platelet counts did not rise over $20 \times 10^{9} / 1$.

\section{Results}

Results of treatment with danazol are presented in Table II. Five of the seven patients improved under danazol. Three had 'excellent', one 'good' and one a 'transient' response. Two of the excellent responders (Nos 1,3 ) have maintained their platelet counts above $100 \times 10^{9} / 1$ for 44 and 51 months, with danazol being the only treatment. In patient No. 1 the discontinuation of danazol was associated with a significant reduction of platelet counts, while readministration was repeatedly followed by a rise to normal values. In patient No. 7 after 3 months of treatment with an excellent response the dose of danazol was reduced and platelet count declined to $30 \times 10^{9} / 1$. This value was higher than the one previously observed with prednisone and azathioprine combined. Synergistic effect of prednisone and danazol was noted in the good responder (No. 6), in whom prednisone was reduced from $30 \mathrm{mg}$ daily prior to danazol therapy to $10 \mathrm{mg}$ when the two drugs were given 
Table I Patients' data and treatment regimens prior to danazol therapy

\begin{tabular}{|c|c|c|c|c|c|c|c|}
\hline Patient & $\begin{array}{l}\text { Age } \\
\text { (yrs) }\end{array}$ & Sex & $\begin{array}{l}\text { Duration of } \\
\text { ITP prior } \\
\text { to danazol } \\
\text { (months) }\end{array}$ & Steroids & $\begin{array}{r}P \\
\text { vincristine }\end{array}$ & $\begin{array}{c}\text { evious treatm } \\
\text { colchicine }\end{array}$ & $\begin{array}{l}\text { ent } \\
\text { azathioprine }\end{array}$ \\
\hline 1 & 62 & $\mathbf{F}$ & 235 & + & - & - & - \\
\hline 2 & 84 & $\mathbf{M}$ & 180 & + & - & - & - \\
\hline 3 & 72 & $\mathbf{F}$ & 49 & + & - & - & - \\
\hline 4 & 55 & $\mathbf{F}$ & 38 & + & + & - & + \\
\hline 5 & 61 & $\mathbf{M}$ & 13 & + & + & + & + \\
\hline 6 & 55 & $\mathbf{M}$ & 4 & + & + & + & - \\
\hline 7 & 62 & $\mathbf{F}$ & 12 & + & - & - & + \\
\hline
\end{tabular}

Table II Results of danazol therapy in idiopathic thrombocytopenic purpura

\begin{tabular}{|c|c|c|c|c|c|}
\hline \multirow[b]{2}{*}{ Patient } & \multirow{2}{*}{$\begin{array}{c}\text { Before } \\
\text { danazol }\end{array}$} & \multicolumn{2}{|c|}{ Platelet count $\left(\times 10^{9} / l\right)$} & \multirow{2}{*}{$\begin{array}{c}\text { Duration of } \\
\text { follow up } \\
\text { (months) }\end{array}$} & \multirow[b]{2}{*}{ Response $^{\dagger}$} \\
\hline & & for 1 month & maximal value & & \\
\hline 1 & 50 & 92 & 137 & 44 & Excellent \\
\hline 2 & 18 & 6 & 7.2 & 9 & Poor \\
\hline 3 & 16 & 25 & 122 & 51 & Excellent \\
\hline 4 & 23 & 55 & 55 & 50 & Transient \\
\hline 5 & 11 & 16 & 16 & 8.5 & Poor \\
\hline $6^{*}$ & 9 & 65 & 65 & 40 & Good \\
\hline 7 & 15 & 114 & 209 & 15 & Excellent \\
\hline
\end{tabular}

'Patient stopped danazol because of side effects; ${ }^{\dagger}$ see text for explanation.

simultaneously. In this patient there was a 7-fold elevation in platelet count. This patient was the only one who suffered from side effects of danazol. He had headache and nausea which caused cessation of treatment. One patient exhibited a 'transient' response though danazol was continued. Maximal response was seen within one month of treatment in three of the five responders. No response was noted in two patients.

\section{Discussion}

The potential therapeutic modalities available for patients with ITP who do not respond to steroids are far from being satisfactory.

Immunosuppressive drugs such as vinca alkaloids, cyclophosphamide and azathioprine have been shown to produce a rise in platelet counts in some patients. However, side effects, mainly bone marrow suppression and sterility, together with the short lived effect of vinca alkaloids and the carcinogenic potential of cyclophosphamide and azathioprine are major disadvantages. Splenectomy, besides having operative and post-operative hazards does not benefit all patients. High dose intravenous immunoglobulin IgG is very expensive and only of temporary effect.
Danazol for refractory ITP was first introduced in 1983 by Ahn et al. with encouraging results. ${ }^{6}$ Fifteen out of 22 patients $(68 \%)$ were improved and in $11(50 \%)$ sustained normal platelet counts for 2-3 months were recorded. These results seemed especially promising, as danazol has been utilized for the management of many nonhaematological disorders in the last 15 years without significant side effects. ${ }^{2.6-8,11-14}$ The mechanism of danazol activity in ITP is not clear. Animal experiments suggest that it reduces antibody secretion by enhancing the function of suppressor cells, ${ }^{2}$ but the study of the effect of danazol on the level of antiplatelet antibodies in patients with autoimmune thrombocytopenia has yielded conflicting results. ${ }^{15}$ Danazol also suppresses macrophage activity $^{2}$ and may mediate its clinical effect at least in part by decreasing the number of available Fc (IgG) receptors on human monocytes. ${ }^{16}$ It appears to be an effective immune modulator which increases $T$ helper/inducer cells in patients with autoimmune thrombocytopenia. ${ }^{17}$

The results of clinical studies following the first report ${ }^{6}$ are inconsistent (Table III). In two, a beneficial effect was seen: in one, ${ }^{8}$ all three patients demonstrated various degrees of response; in the other, 9 out of 14 patients $(50 \%)$ responded and 5 had a sustained complete remission. 
Table III Data from published studies using danazol for the treatment of idiopathic thrombocytopenic purpura

\begin{tabular}{|c|c|c|c|}
\hline Author & $\begin{array}{c}\text { Danazol } \\
\text { dosage } \\
\text { mg/day }\end{array}$ & $\begin{array}{c}\text { No. of } \\
\text { splenectomized } \\
\text { patients/total no. } \\
\text { of patients }\end{array}$ & $\begin{array}{l}\text { Results" } \\
\text { no. of benefited } \\
\text { patients/total } \\
\text { no. of patients }\end{array}$ \\
\hline $\begin{array}{l}\text { Ahn }^{6} \\
\text { Mcvery }^{3} \\
\text { Heyd }^{8} \\
\text { Buelli9 }^{9} \\
\text { Almagro }\end{array}$ & $\begin{array}{c}400-800 \\
600 \\
800 \\
600 \\
400-800\end{array}$ & $\begin{array}{c}15 / 22 \\
6 / 10 \\
3 / 3^{\dagger} \\
6 / 14 \\
\ddagger\end{array}$ & $\begin{array}{l}\text { Favourable } 15 / 22 \\
\text { Non-favourable } 3 / 10 \\
\text { Favourable } 3 / 3 \\
\text { Favourable } 7 / 14 \\
\text { Non-favourable } 2 / 9\end{array}$ \\
\hline
\end{tabular}

"Favourable $-50 \%$ or more response rate; non-favourable $-30 \%$ or less response rate. ${ }^{\dagger}$ One patient underwent splenectomy after secondary danazol failure. ${ }^{\ddagger}$ No data on the number of patients who underwent splenectomy before danazol.

In contrast, in two other studies results were much less encouraging. In one study only one out of 10 patients had a sustained increase in platelet counts and two others had transient response; in the second, ${ }^{10}$ only one single patient out of 9 showed long-term normalization of platelet counts while in another a transient response was noted. The reason for the different results is not clear. Whether different patient populations or differences in danazol dosage, which was not uniform for all patients reported, cause the discrepant results, cannot be determined. Our data, although based on a small group of patients, are in accordance with those of Ahn et al. ${ }^{6}$ and also show various degrees of improvement in 5/7 of the patients. Moreover, in all previous studies the majority of the patients were splenectomized. Clinical experience with danazol in nonsplenectomized patients has been very limited so far.

Danazol was found useful in the treatment of refractory autoimmune thrombocytopenia associ- ated with systemic lupus'erythematosus ${ }^{15}$ and in all 6 patients thrombocytopenia resolved within 6 weeks of the addition of danazol treatment to the previously existing medications. For two of the patients glucocorticoids had failed, for one patient glucocorticoids and azathioprine had failed, for another glucocorticoids and splenectomy had failed and for the remaining two patients glucocorticoids, splenectomy and azathioprine had been unhelpful.

The effectiveness of danazol in steroid resistant patients on the one hand and its safety on the other, raises the possibility that this drug should be considered among the first line therapeutic modalities available for the treatment of ITP. Its introduction before splenectomy and/or immunosuppressives may be not infrequently associated with favourable results and might save splenectomy in many patients. The optimal doses for induction of response and for its maintenance, as well as the duration of therapy remain to be determined in future controlled studies in a larger group of ITP patients.

\section{References}

1. McMillan, R. Chronic idiopathic thrombocytopenic purpura. $N$ Engl J Med 1981, 304: 1135-1147.

2. Harrington, W.J. Generalized bleeding interpreting clinical findings. Hosp Pract 1985, 20 (1A): 75-90.

3. McVerry, B.A., Auger, M. \& Bellingham, A.J. The use of danazol in the management of chronic immune thrombocytopenic purpura. Br J Haematol 1985, 61: 145-148.

4. Karpatkin, S. Autoimmune thrombocytopenic purpura. Blood 1980, 50: 329-343.

5. Ahn, Y.S. \& Harrington, W.J. Treatment of idiopathic thrombocytopenic purpura (ITP). Ann Rev Med 1977, 28: 299-309.

6. Ahn, Y.S., Harrington, W.J., Simon, S.R. et al. Danazol for the treatment of idiopathic thrombocytopenic purpura. $N$ Engl J Med 1983, 308: 1396-1399.

7. Madanes, A.E. \& Farber, M. Danazol. Ann Intern Med 1982 , 96: $625-630$.

8. Heyd, J. \& Hershko, C. Use of danazol in the management of chronic idiopathic thrombocytopenic purpura. Isr J Med Sci 1985, 21: 418-420.

9. Buelli, M., Cortelazzo, S., Viero, P. et al., Danazol for the treatment of idiopathic thrombocytopenic purpura. Acta Hematol (Basel) 1985, 74: 97-98.

10. Almagro, D. Danazol in idiopathic thrombocytopenic purpura. Acta Hematol (Basel) 1985, 74: 120.

11. Gadek, J.E., Fulmer, J.D., Gelfand, J.A. et al., Danazolinduced augmentation of serum alpha 1 antitrypsin levels in individuals with marked deficiency of this antiprotease. J Clin Invest 1980, 66: 82-87.

12. Hosea, S.W., Stantaella, M.L., Brown, E.J. et al., Long-term therapy of hereditary angioedema with danazol. Ann Intern Med 1980, 93: 809-812. 
13. Morley, K.D., Parke, A. \& Hughes, G.R.V. Systemic lupus erythematosus, two patients treated with danazol. $\mathrm{Br} \mathrm{Med} \mathrm{J}$ 1982, 284: 1431-1432.

14. Fretwell, M.D. \& Altman, L.C. Exacerbation of a lupus erythematosus like syndrome during treatment of non $\mathrm{Cl}$ esterase inhibitor-dependent angioedema with danazol. $J$ Allergy Clin Immunol 1982, 69: 309-310.

15. West, S.G. \& Johnson, S.C. Danazol for the treatment of refractory autoimmune thrombocytopenia in systemic lupus erythematosus. Ann Intern Med 1988, 108: 703-706.
16. Schreiber, A.D., Chien, P., Tomaski, A. \& Cines, D.B. Effect of danazol in immune thrombocytopenic purpura. $N$ Engl $J$ Med 1987, 316: 503-508.

17. Mylvaganam, R., Ahn, Y.S., Harrington, W.J. \& Kim, C.J. Immune modulation by danazol in autoimmune thrombocytopenia. Clin Immunol Immunopathol 1987, 42: 281 - 297. 